\title{
Evaluasi Alih Fungsi Lahan Pertanian Menjadi Lahan Industri di Kabupaten Kendal Tahun 2014 - 2018
}

\author{
Evaluation of Land Use Change of Agricultural Land into Industrial Area in Kendal Regency in Period \\ 2014-2018
}

\author{
Fitrian Adiyaksa1, Prijono Nugroho Djojomartono² \\ ${ }^{1}$ Alumni Departemen Teknik Geodesi FT-UGM, Indonesia \\ 2 Staf Pengajar Departemen Teknik Geodesi FT-UGM, Indonesia
}

Penulis Korespondensi: Prijono Nugroho Djojomartono | Email: prinug@ugm.ac.id

Diterima (Received): 17/Apr/2020 Direvisi (Revised): 12/May/2020 Diterima untuk Publikasi (Accepted): 1/Jun/2020

\begin{abstract}
ABSTRAK
Kabupaten Kendal merupakan wilayah yang agraris dengan prosentase lahan pertanian 54,57 \% dari total luas lahan $1.002,23 \mathrm{~km}{ }^{2}$. Wilayah tersebut termasuk dalam metropolitan Kendal, Demak, Ungaran, Semarang, dan Purwodadi (Kedungsepur). Seiring dicanangkannya program pemerintah terkait pembangunan Kawasan Industri Kendal (Kendal Industrial Park) yang dibangun di atas lahan seluas 2.700 hektar. Sebagian lahan yang digunakan untuk pembangunan Kawasan Industri Kendal merupakan lahan pertanian. Hal tersebut menjadikan adanya alih fungsi lahan atau konversi lahan dari lahan pertanian menjadi lahan industri. Penelitian ini bertujuan untuk mengevaluasi kesesuaian alih fungsi lahan pertanian menjadi lahan industri di Kabupaten Kendal dari tahun 2014 s.d. 2018 terhadap Rencana Tata Ruang Wilayah (RTRW) Kabupaten Kendal tahun 2011-2031. Metode penelitian yang digunakan adalah metode kuantitatif. Metode pengumpulan data dalam penelitian ini menggunakan metode sensus data izin lokasi maupun izin perubahan penggunaan tanah (IPPT) di wilayah Kabupaten Kendal dalam kurun waktu 2014 s.d. 2018. Teknik pengumpulan data pada penelitian ini dilakukan dengan studi dokumen data sekunder dari instansi terkait. Teknik analisis data pada penelitian ini terbagi atas analisis spasial dan analisis statistik. Teknik analisis spasial yang digunakan menggunakan konsep Sistem Informasi Geografis (SIG) yaitu metode overlay pada peta-peta digital. Analisis statistik digunakan untuk menghasilkan informasi berupa tabel dan grafik. Hasil penelitian ini menunjukkan pola pertumbuhan alih fungsi lahan pertanian menjadi industri di Kabupaten Kendal yang cenderung mengalami peningkatan. Tercatat bahwa sejak 2014 s.d. 2018, jumlah izin terkait alih fungsi sebanyak 134 izin dengan rincian 34 izin lokasi seluas $732.792 \mathrm{~m}^{2}$ dan 100 IPPT seluas $690.303 \mathrm{~m}^{2}$. Pertumbuhan alih fungsi lahan secara rinci direpresentasikan pada tabel, grafik dan peta pertumbuhan alih fungsi lahan pertanian menjadi industri. Kesesuaian alih fungsi lahan pertanian menjadi industri di Kabupaten Kendal dari tahun 2014 s.d. 2018 sebagian besar telah sesuai dengan RTRW. Dengan rincian sebanyak 91,18 \% izin lokasi industri dan 62 \% IPPT pertanian menjadi industri telah sesuai dengan RTRW Kabupaten Kendal tahun 2011 s.d. 2031.
\end{abstract}

Kata Kunci: Alih fungsi lahan, Overlay, Rencana Tata Ruang Wilayah

\section{ABSTRACT}

Kendal Regency is an agrarian area with a percentage of agricultural land 54.57\% of the total land area of 1,002.23 $\mathrm{km}^{2}$. With the government programs of construction of the Kendal Industrial Park (Kendal Industrial Park) which was built on an area of 2,700 hectares. Most of the land used for development of the Kendal Industrial Area is agricultural land. The purpose of this study was evaluated about the suitability of land use change from agricultural land into industrial land in Kendal Regency in period of 2014 to 2018 with the Kendal Regency Regional Spatial Plan in 2011 - 2031. The research method was quantitative. The method of data collection in this study was census about industry location permit and land use change permit in Kendal Regency from 2014 to.d. 2018. The data collection technique in this research was documents review about secondary data from related institutions. Data analysis techniques in this study were divided into spatial analysis and statistical analysis. The spatial analysis technique used Geographic Information System (GIS) concept, and used overlay method on digital maps. Statistical analysis used to produce information in tables and graphs. The results of this study indicate about the growth in period 2014 to 2018, the number of land use permits increase to 134 permits devide by 34 industry location permit with covering area about 732,792 $\mathrm{m}^{2}$ and 100 land use change permit with covering area equal 690,303 $\mathrm{m}^{2}$. In addition, 
about $91.18 \%$ of industrial location permits and $62 \%$ of land use change permits from agriculture into industries in accordance with the Kendal Regional Spatial Plan between 2011 to 2031.

Keywords: landuse change, Overlay, regional spatial plan

(C) Author(s) 2020. This is an open access article under the Creative Commons Attribution-ShareAlike 4.0 International License (CC BY-SA 4.0).

\section{Pendahuluan}

Kebutuhan lahan cenderung terus mengalami peningkatan sering meningkatnya jumlah penduduk dan perkembangan struktur perekonomian (Al-Vatia \& Djojomartono, 2019). Hal demikian akan memunculkan kecenderungan terjadinya alih fungsi lahan untuk pemenuhan kebutuhan akan lahan untuk berbagai macam kepentingan. Tak terkecuali alih fungsi lahan pertanian untuk sektor non pertanian (Iqbal, 2007; Syafitri \& Santosa, 2020). Kabupaten Kendal yang termasuk dalam wilayah metropolitan Kedungsepur (Kendal, Demak, Ungaran, Semarang, dan Purwodadi) cenderung mengalami perkembangan sektor industri yang signifikan. Hal tersebut menjadikan kebutuhan akan lahan industri cenderung meningkat seiring dicanangkannya program pemerintah terkait pembangunan Kawasan Industri Kendal (Kendal Industrial Park) pada tahun 2016 seluas 2.700 hektar. Sebagian lahan yang digunakan untuk pembangunan Kawasan Industri tersebut berasal dari lahan pertanian yang dinilai kurang produktif (Kementrian Perindustrian, 2016). Secara spasial Kabupaten Kendal tersebut memiliki luas wilayah sebesar 1.002,23 $\mathrm{km}^{2}$ dalam 20 kecamatan. Dengan presentase lahan yang dipergunakan untuk tanah sawah sebesar 25,93\%, tegalan 20,89\%, hutan 15,69\%, dan perkebunan $7,85 \%$. Sedangkan luas lahan bukan pertanian sebesar 23,71 \%, dan untuk sektor lainnya sebesar 5.93 \% (BPS Kendal, 2017).

Sebagaimana dikemukakan oleh Leonataris (2012) bahwa, pengunaan lahan terbangun di Kota Bekasi dari tahun 2003 s.d. 2010 mengalami peningkatan yang cukup signifikan. Hal ini menunjukkan bahwa suatu wilayah yang memiliki tingkat aksesibilitas yang tinggi, maka semakin tinggi pula aktivitas yang mendorong terjadinya perubahan penggunaan lahan di suatu wilayah tersebut. Selain itu, perkembangan sektor industri menyebabkan kebutuhan akan lahan industri juga semakin meningkat. Sebagaimana dikemukakan oleh Nuryanaputri (2015) bahwa, perubahan lahan pertanian menjadi lahan industri di Kabupaten Nganjuk pada periode 2011 s.d. 2014 mengalami peningkatan sebesar $716.981 \mathrm{~m}^{2}$ atau 0,11\%. Melihat kondisi tersebut, peningkatan alih fungsi lahan pertanian menjadi lahan industri perlu diperhitungkan dan dievaluasi agar alih fungsi lahan di suatu wilayah dapat terlaksana sesuai dengan perencanaan. Menurut Kusumasari (2015), perubahan penggunaan tanah di Kabupaten Kulon Progo terdapat ketidaksesuaian seluas 808.666,1542 $\mathrm{m}^{2}$ atau $56,62 \%$ dari total luas perubahan penggunaan tanah yang ada seluas $1.430 .837,16 \mathrm{~m}^{2}$. Hal ini menunjukkan bahwa, perubahan penggunaan tanah di suatu wilayah perlu dievaluasi secara periodik, agar ketidaksesuaian perubahan penggunaan tanah dapat terukur secara spasial.

Tujuan dari penelitian ini adalah memetakan pertumbuhan dan kesesuaian alih fungsi lahan pertanian menjadi lahan industri di Kabupaten Kendal dalam kurun waktu tahun 2014 s.d. 2018. Evaluasi yang dilakukan diharapkan mampu memberikan gambaran tentang pertumbuhan alih fungsi lahan pertanian menjadi industri serta kesesuaian alih fungsi lahan tersebut terhadap Rencana Tata Ruang Wilayah (RTRW). Informasi terkait alih fungsi lahan dari pemetaan yang dilakukan diharapkan dapat bermanfaat untuk pihak-pihak yang terlibat langsung dalam kegiatan alih fungsi lahan maupun masyarakat pada umumnya.

\section{Data dan Metodologi}

\subsection{Data dan Lokasi}

Penelitian ini dilakukan di Kabupaten Kendal, Provinsi Jawa Tengah. Khususnya pada 11 kecamatan dimana terdapat izin lokasi industri maupun izin perubahan penggunaan tanah (IPPT). Lokasi secara detail dijelaskan pada bagian hasil. Adapun data yang digunakan daam penelitian meliputi: Data izin lokasi dan IPPT Kabupaten Kendal tahun 2014 s.d. 2018 skala 1:500 s.d. 1:5.000, Peta administrasi Kabupaten Kendal tahun 2011 skala 1:50.000, peta penggunaan lahan Kabupaten Kendal tahun 2011 skala 1:50.000, dan Peta Rencana Pola Ruang RTRW Kabupaten Kendal tahun 2011 s.d. 2031 skala 1:50.000. Data yang digunakanan tersebut merupakan data digital dengan format data shapefile (.shp). Sistem proyeksi pada masing-masing data tersebut adalah Universal Transverse Mercator (UTM) pada Zona 49 South. Data alih fungsi lahan dalam penelitian dibatasi pada alih fungsi lahan pertanian menjadi lahan industri bertujuan agar penelitian lebih spesifik. Kategori industri yang dimaksud terbatas pada industri skala besar yang telah tercatat pada instansi terkait.

\subsection{Metodologi}

Metode penelitian yang digunakan dalam penelitian ini adalah metode penelitian kuantitatif. Observasi yang digunakan yaitu sensus, dimana dapat betul-betul representative (mewakili) alih fungsi lahan pertanian menjadi lahan industri di Kabupaten Kendal dalam kurun watu 2014 s.d. 2018. Secara garis besar diagram penelitian dapat dilihat di Lampiran A. 
Pengumpulan data pada penelitian ini dilakukan dengan teknik studi dokumen. Jenis dokumen yang dipergunakan dalam penelitian bersifat sekunder, artinya diperoleh dari instansi terkait. Adapun instansi yang dimaksud yaitu: Kementrian Agraria dan Tata Ruang/ Badan Pertanahan Nasional (ATR/BPN) Kabupaten Kendal terkait dengan data izin lokasi maupun IPPT, dan Badan Perencanaan, Penelitian dan Pengembangan (Baperlitbang) Kabupaten Kendal terkait dengan data peta administrasi, peta penggunaan lahan, dan peta RTRW (pola ruang).

Teknik analisis data pada penelitian ini terbagi atas analisis spasial dan analisis statistik. Teknik analisis spasial menggunakan konsep Sistem Informasi Geografis (SIG). Analisis spasial dan pembuatan peta menggunakan perangkat lunak ArcGIS versi 10.3. Analisis spasial yang digunakan adalah overlay pada peta-peta digital. Analisis statistik pada penelitian ini menggunakan statistik deskriptif. Penelitian ini berstandar pada pengukuran persebaran dan pemusatan data dalam statistik. Secara teknis, analisis spasial yang dilakukan meliputi:

1. Pembuatan Peta Persebaran Alih Fungsi Lahan Pertanian menjadi Industri

Pada peta tersebut dilakukan overlay pada data izin lokasi maupun IPPT dengan peta administrasi. Data peta administrasi memiliki unit spasial desa/kelurahan. Pada data spasial terkait izin lokasi maupun IPPT memiliki unit spasial bidang tanah, dalam hal ini data tersebut dilakukan generalisasi sehingga kedua data memiliki skala yang sama yaitu 1:50.000. Jenis overlay yang digunakan yaitu union. Unit spasial pada peta yang dihasilkan yaitu kabupaten. Peta disajikan pada skala 1:175.000.

2. Pembuatan Peta Kesesuaian Alih Fungsi Lahan Pertanian menjadi Industri

Analisis dilakukan melalui berbagai perbandingan data baik data perizinan (izin lokasi dan IPPT) maupun data pembanding untuk mengetahui tingkat kesesuaiannya yaitu lampiran peta Rencana Tata Ruang Wilayah Kabupaten (RTRWK) pada Peraturan Daerah Kabupaten Kendal Nomor 20 Tahun 2011 tentang Rencana Tata Ruang Wilayah Kabupaten Kendal Tahun 2011 - 2031. (Pemerintah Kabupaten Kendal, 2011). Jenis overlay yang digunakan yaitu union dan intersect. Peta disajikan pada skala 1:50.000 dan 1:75.000.

Hasil pada analisis spasial disajikan dalam bentuk peta yang diolah menggunakan perangkat lunak ArcGIS. Peta-peta yang dimaksud yaitu Peta persebaran alih fungsi lahan, dan peta kesesuaian alih fungsi lahan. Hasil pada analisis statistik disajikan dalam bentuk tabel dan grafik, meliputi grafik pertumbuhan alih fungsi lahan dan tabel kesesuaian alih fungsi lahan. Setelah dilakukan analisis spasial, kemudian data tersebut dilakukan analisis statistik untuk mengukur pertumbuhan dan mengetahui tingkat kesesuaian alih fungsi lahan. Analisis tersebut meliputi:

1. Analisis Pertumbuhan Alih Fungsi Lahan Pertanian menjadi Industri
Analisis tersebut dilakukan dalam lingkup kabupten untuk mengukur besarnya tingkat pertumbuhan alih fungsi lahan. Menurut Parker (2002) untuk mengetahui nilai pertumbuhan pada setiap tahun maka dihitung menggunakan growth rates. maka dihitung dengan rumus (1).

$$
G R=\frac{v_{b}-v_{a}}{v_{a}} \times 100
$$

Keterangan:

GR : Growth rates

$\mathrm{V}_{\mathrm{a}}$ : Nilai awal

$\mathrm{V}_{\mathrm{b}}$ : Nilai akhir

Untuk mengetahui prosentase pertumbuhan ratarata setiap tahunnya maka digunakan percent rate (Parker, 2002). Perhitungan tersebut dapat menggunakan persamaan (2).

$$
P R=\frac{v_{b}-v_{a}}{t_{b}-t_{a}} \times 100
$$

Keterangan:

PR : Percent rate

$\mathrm{V}_{\mathrm{a}}$ : Nilai awal

$\mathrm{V}_{\mathrm{b}}$ : Nilai akhir

$t_{a}$ : Waktu pada nilai awal

$t_{b}$ : Waktu pada nilai akhir

2. Analisis Kesesuaian Alih Fungsi Lahan Pertanian menjadi Industri

Pada tahap ini tingkat kesesuaian dibagi berdasarkan jenis izin. Pada masing-masing jenis izin dihitung prosentase kesesuaian berdasarkan jumlah izin alih fungsi lahan dan prosentase berdasarkan luas alih fungsi lahan yang sesuai dengan RTRW.

\section{Hasil dan Pembahasan}

3.1. Sebaran Alih Fungsi Lahan Pertanian menjadi Industri

Sebaran alih fungsi lahan direpresentsikan dalam bentuk peta skala 1:175.000. Peta tersebut mencakup wiayah keseluruhan Kabupaten Kendal dengan unit spasial kecamatan. Untuk mengetahui sebaran alih fungsi lahan maka dapat dilihat pada gambar 3.1.

Untuk memudahkan mengetahui tingkat persebaran alih fungsi lahan pada gambar 3.1 maka peta disajikan dengan menggunakan gradasi warna. Tingkat gradasi warna yang semakin gelap menunjukkan bahwa jumlah alih fungsi lahan pertanian menjadi industri semakin tinggi, sedangkan pada kecamatan yang memliki tingkat alih fungsi lahan yang lebih rendah maka disimbolkan dengan warna yang lebih terang. Secara statistik, sebaran fungsi lahan pertanian menjadi industri dapat tersaji pada tabel 3.1.

Berdasarkan tabel 3.1 di atas, alih fungsi lahan pertanian di Kabupaten Kendal dalam kurun waktu 2014 s.d. 2018 tersebar dalam 11 kecamatan. Prosentase alih fungsi lahan pertanian menjadi industri terjadi paling banyak di Kecamatan Kaliwungu. Tercatat sebanyak 93 izin atau 69,4 \% dengan rincian 31 izin lokasi dan 62 IPPT, diikuti Kecamatan Boja sebanyak 16 izin atau 11,94 \% dengan 
rincian 1 izin lokasi dan 15 IPPT, kemudian diikuti Kecamatan Gemuh sebanyak 7 IPPT atau 5,22 \%.

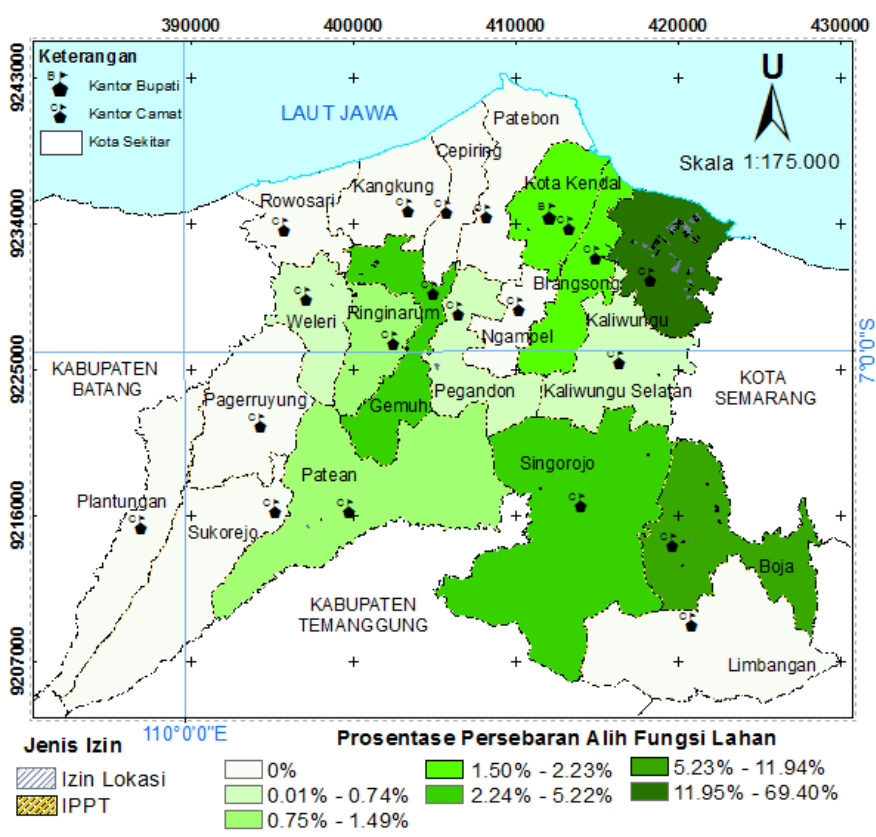

Gambar 3.1 Peta sebaran alih fungsi lahan

Tabel 3.1 Sebaran alih fungsi lahan setiap kecamatan

\begin{tabular}{lcrcr}
\hline \multirow{2}{*}{ Kecamatan } & \multicolumn{2}{c}{ Izin Lokasi } & \multicolumn{2}{c}{ IPPT } \\
\cline { 2 - 5 } & Jumlah & $\begin{array}{c}\text { Luas } \\
\left(\mathbf{m}^{2}\right)\end{array}$ & Jumlah & \multicolumn{1}{c}{$\begin{array}{l}\text { Luas } \\
\mathbf{( m}^{\mathbf{2}} \mathbf{y}\end{array}$} \\
\hline Boja & 1 & 534 & 15 & 50.953 \\
\hline Brangsong & 0 & 0 & 3 & 4.296 \\
\hline Gemuh & 0 & 0 & 7 & 30.441 \\
\hline Kaliwungu & 31 & 689.204 & 62 & 566.925 \\
\hline $\begin{array}{l}\text { Kaliwungu } \\
\text { Selatan }\end{array}$ & 0 & 0 & 1 & 2.227 \\
\hline $\begin{array}{l}\text { Kota } \\
\text { Kendal }\end{array}$ & 0 & 0 & 3 & 4.365 \\
\hline Patean & 1 & 13.564 & 1 & 5.000 \\
\hline Pegandon & 1 & 29.490 & 0 & 0 \\
\hline Ringinarum & 0 & 0 & 2 & 9.604 \\
\hline Singorojo & 0 & 0 & 5 & 13.765 \\
\hline Weleri & 0 & 0 & 1 & 2.727 \\
\hline Total & 34 & 732.792 & 100 & 690.303 \\
\hline
\end{tabular}

3.2 Pertumbuhan Alih Fungsi Lahan Pertanian menjadi Lahan Industri

Untuk memudahkan memperoleh informasi terkait alih fungsi lahan maka data izin diseleksi berdasarkan jenis kegiatan yaitu izin lokasi dan IPPT. Seleksi data diperlukan untuk memudahkan pengambilan informasi dan bertujuan untuk menghindari redundansi data terkait luas dari izin lokasi dan IPPT yang tumpang tindih. Berdasarkan seleksi data yang telah dilakukan, untuk setiap izin lokasi dapat memuat beberapa IPPT namun setiap IPPT hanya mengacu pada satu izin lokasi saja. Berdasarkan data yang telah melalui proses analisis statistik, maka hasil dari pengolahan data disajikan dalam bentuk grafik pada gambar 3.2 dan 3.3 .

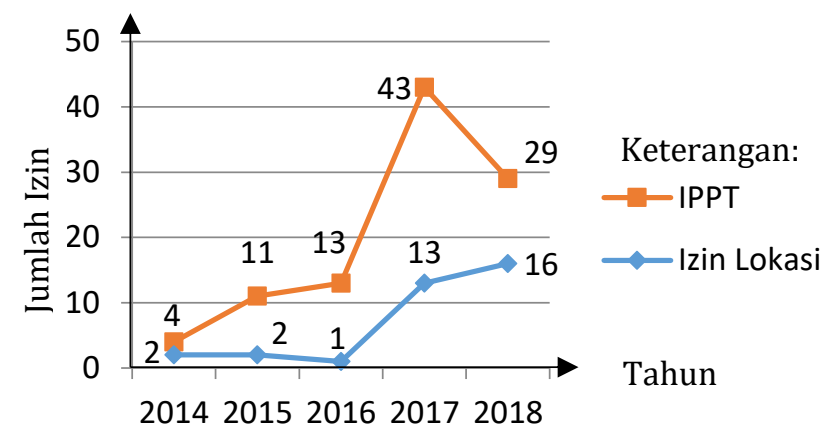

Gambar 3.2 Grafik pertumbuhan ijin berdasarkan jumlah

Pertumbuhan alih fungsi lahan pertanian di Kabupaten Kendal dalam kurun waktu 2014 s.d. 2018 seperti pada gambar 3.2 menunjukkan bahwa pola pertumbuhan jumlah izin dari tahun 2014 s.d. 2016 mengalami peningkatan jumlah. Tercatat tahun 2014 sebanyak 2 izin lokasi dan 4 IPPT, 2015 sebanyak 2 izin lokasi dan 11 IPPT, dan tahun 2016 tercatat sebanyak 1 izin lokasi dan 13 IPPT. Kemudian peningkatan secara signifikan terjadi pada tahun 2017 dimana jumlah izin yang semula dalam kisaran belasan izin menjadi kisaran puluhan izin. Tercatat bahwa pada tahun 2017, jumlah izin lokasi mencapai 13 izin dan IPPT sejumlah 43. Selanjutnya pada tahun 2018 jumlah izin tetap pada kisaran puluhan izin tetapi tidak sebanyak tahun 2017. Pada kurun waktu 2018 tercatat penambahan sebanyak 16 izin lokasi dan 29 IPPT. Untuk mengetahui pola penggunaan lahan industri yang berasal dari lahan pertanian maka perlu melihat pola alih fungsi lahan pertanian menjadi industri berdasarkan luas dari izin, baik izin lokasi maupun IPPT. Untuk memudahkan memahami pola yang ditinjau dari aspek luas lahan maka dapat dilihat pada Gambar 3.3.

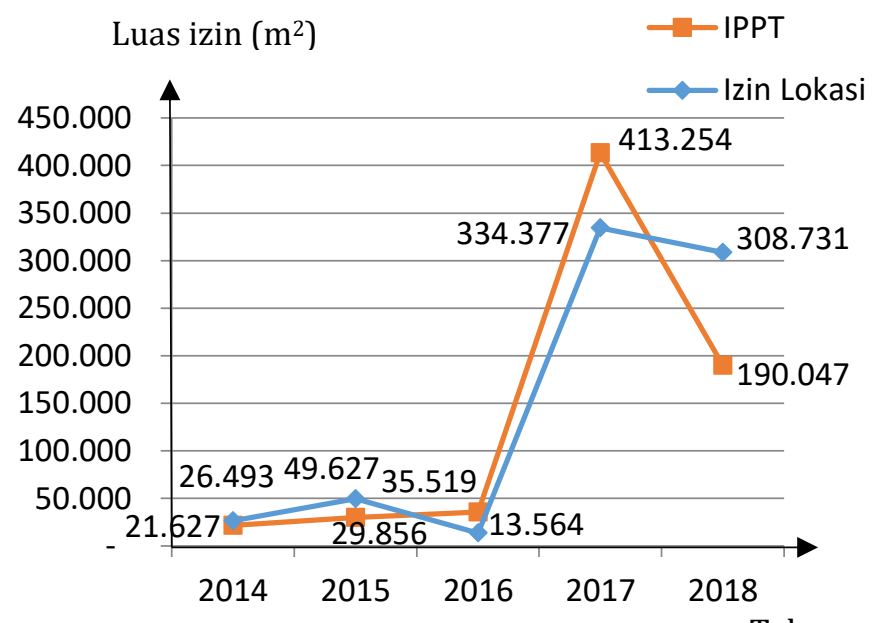

Tahun

Gambar 3.3 Grafik pertumbuhan ijin berdasarkan luas

Berdasarkan gambar 3.3 di aas, pertumbuhan alih fungsi lahan terkait dengan luas lahan industri dalam kurun waktu 2014 s.d. 2018 mengalami fluktuasi. Luas area yang mengalami alih fungsi lahan tidak selalu sebanding dengan jumlah izin yang ada. Hal ini bergantung pada luas wilayah pada masing-masing izin itu sendiri. Berdasarkan informasi tersebut, luas wilayah yang mengalami alih fungsi lahan terutama lahan pertanian menjadi industri, terluas 
terdapat pada tahun 2017 dimana terdapat sejumlah IPPT dengan luas total $413.254 \mathrm{~m}^{2}$. Sedangkan paing sedikit terjadi pada tahun 2014 yaitu terdapat empat IPPT dengan total luas sebesar $26.493 \mathrm{~m}^{2}$.

Berdasarkan informasi tersebut, baik secara matematis maupun spasial, pertumbuhan alih fungsi lahan dapat dipetakan dan dihitung secara pasti. Hal ini terlihat bahwa pada tahun 2017 jumlah izin lokasi tercatat sebanyak 13 izin dengan luas sebesar $334.377 \mathrm{~m} 2$, sedangkan pada 2018 tercatat sebanyak 16 izin lokasi seluas $308.731 \mathrm{~m} 2$. Jumlah izin lokasi yang lebih banyak tersebut tidak selalu menunjukkan bahwa luas alih fungsi lahan di lapangan akan menjadi lebih luas. Pada titik ini telah jelas bahwa besarnya jumlah izin tidak selalu sebanding dengan luas lahan yang mengalami alih fungsi. Hal ini menjadikan perlunya perhitungan pertumbuhan perlu dilakukan secara terpisah. Pemisahan perhitungan akan memudahkan analisis pertumbuhan baik dari segi jumlah izin lokasi maupun IPPT berdasarkan luas yang diperoleh dari analisis spasial.

\subsection{Analisis Kesesuaian Alih Fungsi Lahan Pertanian} menjadi Lahan Industri

Analisis kesesuaian yang dilakukan dalam penelitian ini berdasarkan kesesuaian data izin lokasi dan IPPT terhadap peta kriteria yang telah dibuat berdasarkan overlay peta administrasi, peta penggunaan lahan dan peta RTRWK. Secara spasial, analisis kesesuaian dapat dilihat pada gambar 3.4 .

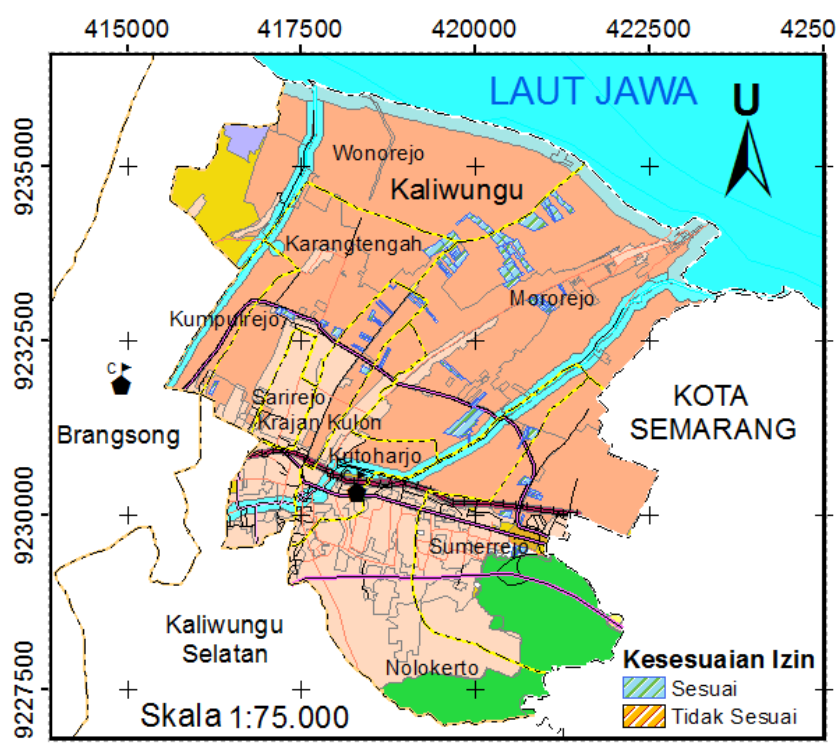

(a)

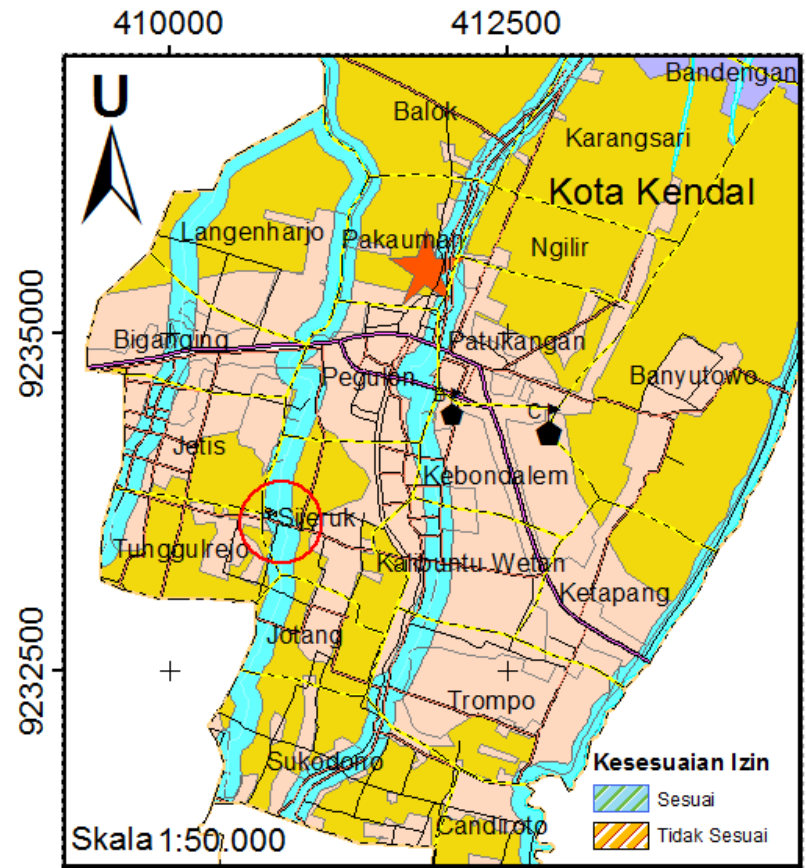

(b)

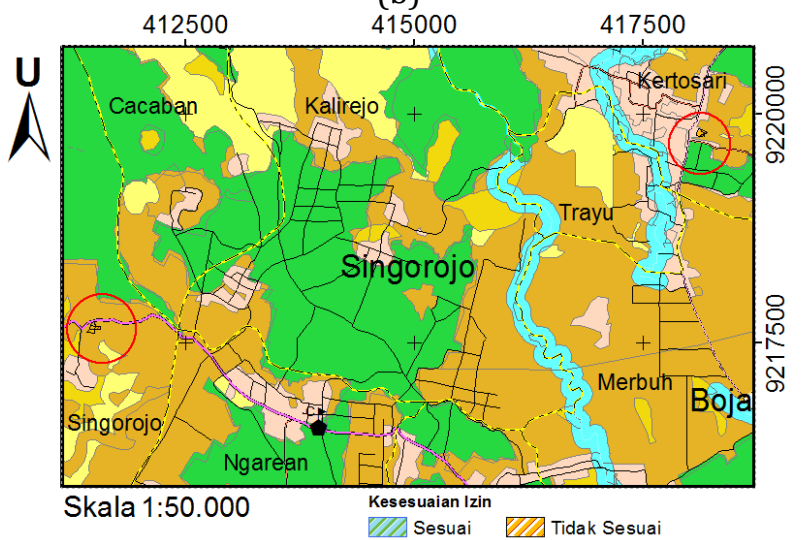

(c)

Gambar 3.4 Evaluasi pada kecamatan (a) Kaliwungu (b)Kota Kendal dan (c) Singorojo

Berdasarkan gambar 3.2 di atas, tingkat kesesuaian alih fungsi lahan dapat ditinjau pada setiap kecamatan. Sebagai ilustrasi pada ketiga kecamatan tersebut dimana setiap data izin dapat dilakukan evaluasi secara spasial terhadap peruntukkan penggunaan lahan pada peta RTRWK. Tingkat kesesuaian alih fungsi lahan pertanian menjadi industri ditinjau dari jenis izin, waktu (tahun perizinan) dan secara kewilayahan mengunakan unit spasial kecamatan. Seperti halnya pada analisis pertumbuhan, pada analisis kesesuaian juga akan dipisahkan berdasarkan jenis izin dan kewilayahan dalam unit spasial kecamatan. Analisis kesesuaian pada jenis izin diklasifikasikan berdasarkan tahun perizinan. Hal ini dapat dilihat pada tabel 3.2. 
Tabel 3.2 Kesesuaian izin lokasi berdasarkan tahun perizinan

\begin{tabular}{crrcc}
\hline \multirow{2}{*}{ Tahun } & \multicolumn{2}{c}{ Izin Lokasi } & \multicolumn{2}{c}{ Kesesuaian } \\
\cline { 2 - 5 } & Jumlah & Luas $\left(\mathbf{m}^{\mathbf{2}}\right)$ & Sesuai & $\begin{array}{c}\text { Tidak } \\
\text { Sesuai }\end{array}$ \\
\hline 2014 & 2 & 26.493 & 2 & 0 \\
\hline 2015 & 2 & 49.627 & 2 & 0 \\
\hline 2016 & 1 & 13.564 & 0 & 1 \\
\hline 2017 & 13 & 334.377 & 12 & 1 \\
\hline 2018 & 16 & 308.731 & 15 & 1 \\
\hline Total & 34 & 732.792 & 31 & 3 \\
\hline
\end{tabular}

Berdasarkan tabel 3.2 terdapat total 34 izin lokasi, sebanyak 31 atau 91,18 \% izin lokasi telah memenuhi syarat dan dapat dikategorikan sesuai dengan RTRWK. Sedangkan hanya terdapat 3 izin atau 8,82 \% yang dikategorikan tidak sesuai dalam kurun waktu tersebut Secara keseluruhan, prosentase kesesuaian izin lokasi untuk keperluan industri telah sesuai dengan RTRWK, namun untuk mengetahui kesesuaian alih fungsi lahan yang digunakan untuk keperluan industri perlu menghitung kesesuian IPPT. Untuk mengetahui prosentase kesesuaian IPPT maka perlu melihat informasi pada tabel 3.3.

Tabel 3.3 Kesesuaian IPPT berdasarkan tahun perizinan

\begin{tabular}{crrcc}
\hline \multirow{2}{*}{ Tahun } & \multicolumn{2}{c}{ IPPT } & \multicolumn{2}{c}{ Kesesuaian } \\
\cline { 2 - 5 } & Jumlah & Luas $\left(\mathbf{m}^{2} \mathbf{)}\right.$ & Sesuai & $\begin{array}{c}\text { Tidak } \\
\text { Sesuai }\end{array}$ \\
\hline 2014 & 4 & 21.627 & 0 & 4 \\
\hline 2015 & 11 & 29.856 & 2 & 9 \\
\hline 2016 & 13 & 35.519 & 5 & 8 \\
\hline 2017 & 43 & 413.254 & 30 & 13 \\
\hline 2018 & 29 & 190.047 & 25 & 4 \\
\hline Total & 100 & 690.303 & 62 & 38 \\
\hline
\end{tabular}

Berdasarkan tabel 3.3 di atas, tercatat sebanyak 100 IPPT pertanian menjadi industri dalam kurun waktu 2014 s.d. 2018. Sebanyak 62 izin atau $62 \%$ IPPT telah sesuai dengan RTRWK, namun terdapat 38 izin atau $38 \%$ IPPT yang tidak sesuai. Hal ini dikarenakan pada tahun 2016 dan sebelumnya, Kabupaten Kendal belum dicanangkan memiliki kawasan industri meskipun telah tertulis dalam Perda mengenai RTRWK yaitu Peraturan Daerah Kabupaten Kendal Nomor 20 Tahun 2011 tentang Rencana Tata Ruang Wilayah Kabupaten Kendal Tahun 2011 - 2031.

Selain ditinjau dari segi tahun perizinan, evaluasi kesesuaian juga ditinjau berdasarkan kewilayahan. Hal ini merupakan hasil dari analisis spasial mengenai kesesuaian pada unit spasial kecamatan. Untuk mengetahui tingkat kesesuaian berdasarkan unit spasial kecamatan, maka dapat dilihat pada tabel 3.4 .
Tabel 3.4 Kesesuaian izin lokasi berdasarkan wilayah kecamatan

\begin{tabular}{lcrl}
\hline \multirow{2}{*}{ Kecamatan } & \multicolumn{2}{c}{ Izin Lokasi } & \\
\cline { 2 - 3 } & Jumlah & \multicolumn{1}{c}{$\begin{array}{c}\text { Luas } \\
\left(\mathbf{m}^{\mathbf{2}} \mathbf{n}\right.\end{array}$} & Kesesuaian \\
\hline Boja & 1 & 534 & Tidak sesuai \\
\hline Brangsong & 0 & 0 & Tidak sesuai \\
\hline Gemuh & 0 & 0 & Tidak sesuai \\
\hline Kaliwungu & 31 & 689.204 & Sesuai \\
\hline $\begin{array}{l}\text { Kaliwungu } \\
\text { Selatan }\end{array}$ & 0 & 0 & Tidak sesuai \\
\hline Kota & 0 & 0 & Tidak sesuai \\
Kendal & 1 & 13.564 & Tidak sesuai \\
\hline Patean & 1 & 29.490 & Tidak sesuai \\
\hline Pegandon & 0 & 0 & Tidak sesuai \\
\hline Ringinarum & 0 & 0 & Tidak sesuai \\
\hline Singorojo & 0 & 0 & Tidak sesuai \\
\hline Weleri & 34 & 732.792 & \\
\hline Total & & & \\
\hline & & & \\
\hline
\end{tabular}

Berdasarkan tabel 3.4 di atas, menunjukkan kesesuaian izin lokasi yang berasal dari alih fungsi lahan pertanian pada setiap kecamatan. Hasilnya, kecamatan yang terdapat perencanaan untuk kawasan industri adalah pada Kecamatan Kaliwungu berdasarkan Perda Kabupaten Kendal No. 20 Tahun 2011 serta lampiran peta RTRWK yang digunakan sebagai data pembanding analisis. Untuk selanjutnya evaluasi kesesuaian akan dilakukan pada jenis kegiatan IPPT. Hal ini dapat dilihat pada tabel 3.5.

Tabel 3.5 Kesesuaian IPPT berdasarkan wilayah kecamatan

\begin{tabular}{lcrl}
\hline \multirow{2}{*}{ Kecamatan } & \multicolumn{2}{c}{ IPPT } & Kesesuaian \\
\cline { 2 - 3 } & Jumlah & $\begin{array}{l}\text { Luas } \\
\left(\mathbf{m}^{2} \mathbf{)}\right.\end{array}$ & \\
\hline Boja & 15 & 50.953 & Tidak sesuai \\
\hline Brangsong & 3 & 4.296 & Tidak sesuai \\
\hline Gemuh & 7 & 30.441 & Tidak sesuai \\
\hline Kaliwungu & 62 & 566.925 & Sesuai \\
\hline $\begin{array}{l}\text { Kaliwungu } \\
\text { Selatan }\end{array}$ & 1 & 2.227 & Tidak sesuai \\
\hline $\begin{array}{l}\text { Kota } \\
\text { Kendal }\end{array}$ & 3 & 4.365 & Tidak sesuai \\
\hline Patean & 1 & 5.000 & Tidak sesuai \\
\hline Pegandon & 0 & 0 & Tidak sesuai \\
\hline Ringinarum & 2 & 9.604 & Tidak sesuai \\
\hline Singorojo & 5 & 13.765 & Tidak sesuai \\
\hline Weleri & 1 & 2.727 & Tidak sesuai \\
\hline Total & 100 & 690.303 & \\
\hline
\end{tabular}

Berdasarkan tabel 3.5 di atas, kesesuaian pada IPPT sama dengan kesesuaian pada izin lokasi. Operasi intersect menghasilkan informasi kesesuaian bidang-bidang tanah pada data izin lokasi dan IPPT pada masing-msing wilayah kecamatan. Hasil dari operasi spasial terebut kemudian diringkas pada tabel 3.4 dan 3.5 di atas. 


\section{Kesimpulan}

Alih fungsi lahan pertanian menjadi industri di Kabupaten Kendal dari tahun 2014 s.d. 2018 mengalami peningkatan yang signifikan. Dari 20 Kecamatan yang ada, terdapat 11 kecamatan yang mengalami peningkatan jumlah lahan industri. Sebagian besar peningkatan terjadi di Kecamatan Kaliwungu karena diproyeksikan menjadi kawasan industri. Pada kurun waktu tersebut terdapat pertambahan luas lahan industri sebesar $690.303 \mathrm{~m}^{2}$ yang terdapat pada 100 IPPT. Alih fungsi lahan pertanian menjadi industri di Kabupaten Kendal dari tahun 2014 s.d. 2018 sebagian besar telah sesuai dengan RTRW. Dengan rincian sebanyak 91,18\% izin lokasi industri dan $62 \%$ IPPT pertanian menjadi industri telah sesuai dengan RTRW Kabupaten Kendal tahun 2011 s.d. 2031.

Tingkat pertumbuhan maupun kesesuaian alih fungsi lahan pertanian menjadi industri dapat dievaluasi secara spasial. Pola kecenderungan sebaran alih fungsi lahan dapat terpetakan sehingga pertambahan lahan industri cenderung pada daerah yang telah direncanakan sebagai kawasan industri. Selain itu, tingkat kesesuaian alih fungsi lahan juga dapat terpetakan dengan unit spasial kecamatan. Hal ini menunjukkan evaluasi yang dilakukan dapat mencakup seluruh data izin yang tercatat pada instansi terkait.

\section{Pernyataan Konflik Kepentingan}

Penulis menyatakan tidak ada konflik kepentingan dalam artikel ini (The authors declare no competing interest).

\section{Referensi}

Al-Vatia, T. V. \& Djojomartono, P. N. (2019). Analysis of the Effect of Land Use Planning and Land Value in Gamping Subdistrict, Sleman, D.I Yogyakarta from 2013 to 2018. Journal of Geospatial Information Science and Engineering, Vol. 2 No. 2 (2019). doi:10.22146/igise.51076
BPS Kendal. 2017. Kabupaten Kendal Dalam Angka. BPS Kabupaten Kendal (Vol. 53). Kendal: Badan Pusat Statistik Kabupaten Kendal.

Iqbal, M. dan Sumaryanto. 2007. Strategi Pengendalian Alih Fungsi Lahan Pertanian Bertumpu Pada Partisipasi Masyarakat. Analisis Kebijakan Pertanian. Volume 5 No. 2, Juni 2007 : 167-182, 5(70)

Kementrian Perindustrian. 2016. Kemenperin Pacu Kawasan Industri Kendal Dongkrak Daya Saing Produk TPT (08/08/2016). Diakses pada 30 November 2018, dari https://kemenperin.go.id/artikel/15869/Kemenperi $\underline{\text { n-Pacu-Kawasan-Industri-Kendal-Dongkrak-Daya- }}$ Saing-Produk-TPT-

Kusumasari, R. D. 2015. Evaluasi Kesesuaian Perubahan Penggunaan Tanah Tahun 2008 -2013 Terhadap Rencana Tata Ruang Wilayah Kabupaten Kulon Progo. Skripsi. Yogyakarta: Universitas Gadjah Mada.

Leonataris, C. 2012. Analisis Pola Perubahan Penggunaan Lahan Dan Perkembangan Wilayah Di Kota Bekasi, Provinsi Jawa Barat. Skripsi. Bogor: Institut Pertanian Bogor.

Nuryanaputri, A. D. 2015. Evaluasi Perubahan Penggunaan Lahan Pertanian Menjadi Lahan Industri di Kabupaten Nganjuk Tahun 2011-2014. Skripsi. Yogyakarta: Universitas Gadjah Mada.

Parker, Bob. 2002. Planning Analysis: Calculating Growth Rates (30 September 2002). Diakses pada 20 September 2019, dari https://pages.uoregon.edu/rgp/PPPM613/class8a.ht $\underline{\mathrm{m}}$

Pemerintah Kabupaten Kendal. 2011. Peraturan Daerah Kabupaten Kendal Nomor 20 Tahun 2011 tentang Rencana Tata Ruang Wilayah Kabupaten Kendal Tahun 2011 - 2031. Kendal: Sekretariat Daerah Kabupaten Kendal.

Syafitri, A. K.N. dan Santosa, P. B. (2020). Spatial Analysis Of Kulon Progo District Development From 2007-2030 With Cellular Automata Markov Model. Proceeding The 1st International Conference on Geodesy, Geomatics, and Land Administration 2019. KnE Engineering Publishing. doi:10.18502/keg.v4i3.5864 
Lampiran A: Diagram Alir Penelitian
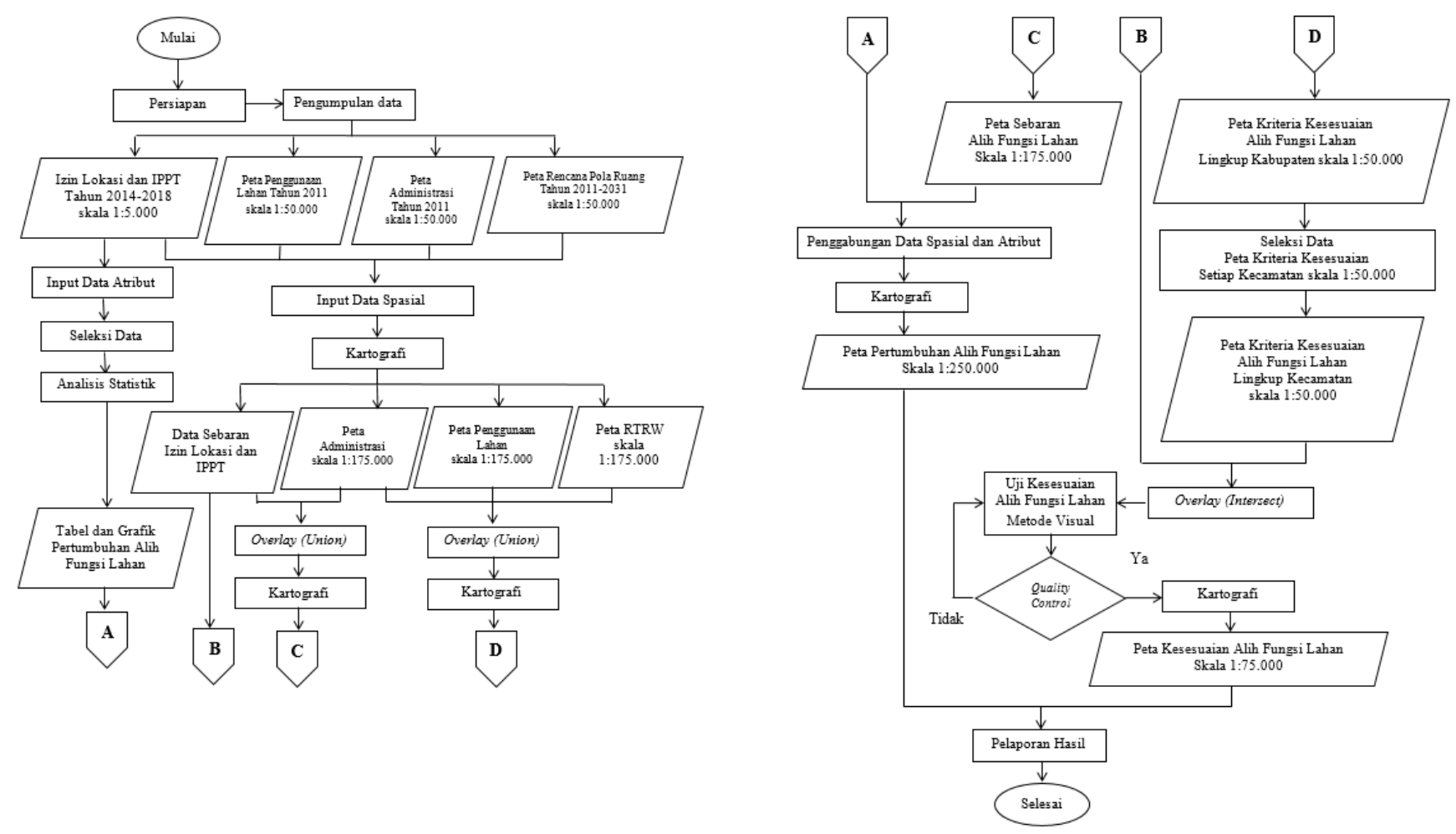